Article

\title{
Business Model Disclosure in the Reporting of Public Companies-An Empirical Study
}

\author{
Aleksandra Szewieczek*(D), Beata Dratwińska-Kania and Aleksandra Ferens \\ Department of Accounting, Finance College, University of Economics in Katowice, ul. 1 Maja 50, \\ 40-287 Katowice, Poland; beatakania@ue.katowice.pl (B.D.-K.); aleksandra.ferens@ue.katowice.pl (A.F.) \\ * Correspondence: aleksandra.szewieczek@ue.katowice.pl
}

check for updates

Citation: Szewieczek, A.; Dratwińska-Kania, B.; Ferens, A. Business Model Disclosure in the Reporting of Public Companies-An Empirical Study. Sustainability 2021, 13, 10088. https://doi.org/10.3390/ su131810088

Academic Editors: Adam Jabłoński, Marek Jabłoński and

Dariusz Zarzecki

Received: 21 July 2021

Accepted: 7 September 2021

Published: 9 September 2021

Publisher's Note: MDPI stays neutral with regard to jurisdictional claims in published maps and institutional affiliations.

Copyright: (c) 2021 by the authors. Licensee MDPI, Basel, Switzerland. This article is an open access article distributed under the terms and conditions of the Creative Commons Attribution (CC BY) license (https:// creativecommons.org/licenses/by/ $4.0 /)$.

\begin{abstract}
Traditional financial reporting primarily discloses information about assets, equity, liabilities and financial situation of an enterprise. Simultaneously, socio-economic changes are prompting enterprises to implement business reporting towards disclosing activities for sustainable development and information about the business model in non-financial reporting. Shaping of an enterprise's business model is carried out in the spirit of sustainable development, which is beginning to dominate the strategies of many large enterprises. At the same time, the concept of the business model and its reporting have still not been characterized in detail or standardized, which limits transparency and the usefulness of information. These phenomena provided an incentive to undertake the research on the business model reporting. The overall goal of this study is to expand research on disclosures about the business model in the corporate reporting of Polish listed companies, as well as to indicate the degree and directions of development of this subject against the background of the accounting system. The study also addresses the epistemological goal by entering the discussion on reporting about the business model. The research uses the financial statement content analysis method and the statistical method (Spearman's correlation). The scope of disclosures about the business model are examined in integrated reports, consolidated reports, management reports, non-financial data reports and CSR reports of Polish companies listed on the stock market. This information is examined according to its four main components: inputs, business activities, outputs and outcomes. The correlation between the number of audited disclosures and selected economic and similar parameters characterizing enterprises (total assets, performance, board, EBITda, equity and liabilities) is also studied. The research reveals that entities preparing an integrated report demonstrate a greater number of disclosures of business model components in selected economic categories than entities that do not prepare such a report. Thus, the companies preparing an integrated report follow the mainstream of stakeholder theory, opting for a more descriptive reporting approach, accessible to a wider group of users. Moreover, business model information is often reported in a highly random manner. Simultaneously, descriptive forms of business model disclosure prevail over numerical ones, although not to a large degree. The findings also confirm that there is a positive correlation between the detail of disclosures about the business model and selected economic parameters of an enterprise (the strongest with total assets, board and EBITda). Thus, it becomes possible to recognize that large enterprises with a strong and stable structure of assets follow specific, more detailed reporting patterns aimed at sustainable development of reporting. At the same time, they are more likely to expand the scope of disclosures compared to smaller enterprises. This investigation responds to the interest of enterprises and other stakeholders in the reporting spectrum by increasing market information efficiency and transparency. Findings can also be used by standards setters, while providing new rules and regulations.
\end{abstract}

Keywords: business model; disclosure; non-financial information; economic parameter; reporting; accounting 


\section{Introduction}

The primary objective of business reporting is to disclose information about the economic results of business activity. An equally important objective is to communicate about the broadly understood activity of enterprises, also in the field of sustainable development. All this is carried out to meet the increasingly sophisticated but also selective needs of an increasing group of enterprises' reporting stakeholders. According to the theory of legitimacy, an enterprise must take into account the requirements of a wider group of users, that is not only investors but also society in general. The scope of information requirements among stakeholders interested in such information is also growing. In this context, there are also changes in the perception of the company, especially its impact on the local economy, community, environment and sustainable development. From a position of one of many elements in the goods and services delivery process, enterprises are becoming significant organisms that may shape their environment. This assumption is in line with the theory of sustainable development. However, the relation also works in the opposite direction.

The guiding purpose of business reporting is to disclose companies' underlying business model [1] and its relations with other elements of various systems (economic, social, environmental and others). The business model (BM) represents the path taken by a company to create value [2]. Research on disclosures about the BM in reporting is justified because it contributes to the understanding of the process of creating value and of the company's implementation of sustainable development. The development of these disclosures results in increased diversity and simultaneously forces actions to improve their quality and usability. At the same time, the BM is a kind of tool for communicating with stakeholders, through which various pieces of information can be announced, reconciling the needs of the many interested groups that may affect the operation of the enterprise, which is in line with modern economic theories, including stakeholder theory [3] and legitimacy theory [4].

The presented topic is highly relevant given the global move towards increasing corporate responsibility. The public is interested in holding businesses accountable, an aspect which the article relates to by focusing on reporting related to business models as a way of communicating business issues and value to all stakeholders. The significance of the study is to focus on showing the tightening relationship between the BM concept and accounting, the specificity of its reflection in company reports and to highlight aspects of its use for creating a company's image. Information on the BM has been examined according to its four main components: inputs, business activities, outputs and outcomes.

Another important research gap is the lack of in-depth research on the disclosure of BM elements, especially in European countries. Poland seems to be a relevant example since it is classified as early adopter country, being on the initial step of the development of integrated reporting, business model reporting and, generally speaking, non-financial reporting. We therefore enrich the emerging literature on integrated reporting by offering empirical evidence on the disclosures about the BM in Polish companies. In order to fill the above gap, this study aims to investigate the number of disclosures regarding companies' BM and the relationships with variables characterizing enterprises such as total assets, performance, board, earnings before interest and taxes (EBITda), equity and liabilities. For this purpose, analysis was conducted of integrated reports, consolidated reports, management reports, non-financial data reports and CSR reports for 2017-2019 from companies in the energy, fuel, mining, telecommunications and banking sectors listed on the Polish stock market (WIG 20).

The following research methods were used in the study: literature studies, critical information analysis, statistical methods (descriptive statistics, Spearman's rank correlation coefficient), deduction and synthesis.

The work contributes to the development of the theory and practice of the field of finance by identifying and filling the gap in information about the components of the business model in different reports and the relationship of the BM with other dimensions 
characterizing an enterprise. As a result, the authors fill an important research gap relating to the debate around the concept of the BM in the area of accounting, especially in the area of non-financial and integrated reporting, which are the pillars of sustainable development reporting. For scholars, this study provides an opportunity to further analyse the trends in integrated thinking and its role in business strategies that combine sustainability, governance and the BM. This study contributes also to the literature by enhancing the understanding of business model reporting practices.

The study also makes a significant contribution to

- A better understanding of the BM relationship with the values that characterize an enterprise from the point of view of sustainable development throughout the entire value chain of the company;

- $\quad$ Laying the foundations for further research on the development of new business models supporting the sustainable development of enterprises.

The study contributes to the discussion on the amount of information published by enterprises. The authors argue that information about the BM is needed, and a greater amount of information published increases research opportunities and shapes good corporate reporting habits, including in terms of environmental protection, for both employees and other market participants. Nowadays, enterprises should disclose how sustainability practices have been integrated into their business strategy, in particular how value has been created over time. Research into different areas of reporting contributes to popularizing the transparency of reporting information, as well as increasing activities promoting sustainable development among enterprises. Companies should offer a comprehensive picture of the social, environmental and economic issues which influence the sustainability of business models. In the literature on understanding a stakeholder's information needs about sustainability issues, an important element is integrated reporting. This should also be reflected in the legal regulations regarding integrated reporting. A valid framework may be particularly beneficial for improving the quality of inherently subjective information such as information about the business model. These activities can increase the potential of integrated reporting in promoting positive changes in communicating about the business model as well as about sustainability [5]. At the same time, according to the authors' knowledge, no one has conducted the research presented in this study before.

The above justifies that presented findings have strong implications for the development of accounting literature and practice, as well as for the development of integrated business reports for transparent demonstration of business intentions and practice.

The remainder of this paper is organized as follows. The section on the theoretical background explains the evolution of the business model concept, presents the basic definitions of the business model, and provides key business model components. The next part of this section relates to analogous research on the business model as reflected in corporate reporting for the development of hypotheses. The following section on research design describes the research sample and data selection process. It defines the research method and main variables. The subsequent section presents the empirical outcomes, while the discussion section presents an analysis of the results with reference to the outcomes of other studies. The last section includes research limitations, a general summary and directions for future research.

\section{Theoretical Framework and Hypotheses Development}

\subsection{Business Model and Corporate Reporting}

The concept of a business model is evolving. Today, it is widely used as a description of activities (including strategic activities) of an entity through elements such as value creation, competitive advantage and firm performance [6,7]. The evolution of the BM is also visible in its definition layer [8-12].

The BM strives to holistically present an enterprise's operations, illustrating the process of creating value and its delivery to customers, as well as capturing this value for the enterprise [13]. The BM is therefore of particular importance in supporting balanced and 
sustainable development as it helps describe, analyse, manage and communicate a firm's proposition regarding sustainable value for customers and all stakeholders, how it creates and delivers this value, and how it creates economic value by preserving or regenerating natural, social and economic capital beyond its organizational boundaries [14]. Companies at various stages of development should build and adapt their BMs in order to maintain their ability to create value for stakeholders [15].

The BM consists of specific components that may be presented in various classifications $[16,17]$. These components, by creating a natural network of related BM elements, enable it to be structured, but most importantly, they often depict the path and tools for creating or losing value in the course of business operations. One such classification, indicated by IIRC, points to four main elements of BM: key inputs (1), key activities (2), outputs (3) and outcomes (4). The enterprise, through the use of key inputs (1), capital and other resources), across its key business activities (2), transforms inputs into outputs (3), key products and services; by-products, emissions, and others) to finally obtain internal and external positive and negative outcomes (4). Outcomes (reputation, employee morale, revenue, cash flows, environmental effects, customer satisfaction, reduction of value, and others), in the short-, medium-, and long-term, generate or decrease value for the organization and for its closer and further environment. Therefore, the BM concept has a financial dimension [18], which directs the research process towards accounting [19], although some researchers question whether there is a need to report on the BM at all [6].

Economic information is largely provided by the accounting system. Increased interest in business models is therefore a determinant as well as simultaneously a result of the development of accounting and its adjustment to changing reporting expectations.

The need for enterprises to report certain additional information to external stakeholders is still not fully theoretically justified [20]. However, the need to extend traditional financial statements with additional information is firmly embedded in theories trying to explain management board decisions in the field of information policy, including in particular stakeholder theory, institutional theory and legitimacy theory. The stakeholder theory, promoted by E. Freeman [21], states that an important element of shaping the relationship of a company with its stakeholders is informing them effectively about the achievements in all areas of the business, as all stakeholders claim the right to decide about the company's matters. All stakeholders also have the right to be informed about how the company affects them, even if they cannot directly influence its business. As result, in this theory, the dominant goal of an enterprise in the form of profit maximization is supplemented with the co-dominant goal of maximizing the social welfare and satisfaction of various stakeholder groups. In this context, it is necessary to maintain balanced relations between various groups of external stakeholders [21] (p. 274).

Essentially, stakeholder theory accepts that different stakeholder groups will have different views about how an organisation should conduct its operations; there will be various social contracts 'negotiated' with different stakeholder groups, rather than one contract with society in general. Whilst implied within legitimacy theory, stakeholder theory explicitly refers to issues of stakeholder power and how a stakeholder's relative power impacts their ability to 'coerce' the organisation into complying with the stakeholder's expectations. According to the stakeholder theory, managers need to balance and mitigate conflicts of interest between shareholders and other stakeholders, which results in the necessity to extend financial disclosure with material nonfinancial information, includiincludeng the $\mathrm{BM}$ [3]. However, it is also important to maintain a balance and a uniform disclosure line in order to avoid information chaos and maintain transparency. As a result, it can be concluded that stakeholder theory underlies the development of reporting, including about the BM.

According to legitimacy theory, society expects an organization to develop its activities in a manner consistent with its beliefs. The enterprise must therefore also take into account the demands of society, not just investors, as well as undertake various kinds of activities aimed at social acceptance of its implemented mission, strategy and operational activities. 
According to this theory, institutions with high social and environmental commitment should be more likely to disclose information on these topics [22].

Institutional theory is important in research on the development of corporate reporting. In relation to this theory [23], organizations engage with a comprehensive system of political, financial, educational, cultural and economic institutions that exert institutional pressure on them. This theory treats the enterprise as an open system that changes in response to social and institutional processes taking place in its environment, legitimizing its actions [22]. Its relationship with information disclosure is that it shows how organizations perceive and respond to changing social and institutional pressures and expectations. In response to the increase in these expectations, the reporting area, including the BM and sustainable development, is also developing. Institutional theory strengthens the system of values on which the assumptions of the theory of legitimacy are based, and the stakeholder theory leads to changes in the system of these values. Legitimacy theory looks at society as a whole, whereas stakeholder theory recognizes that some groups within society are more powerful than others. We posit that the mentioned theories, which are of value in studies into BM reporting, focus upon distinct perspectives of the same issue. The overarching goal of reporting in the context of stakeholder theory and institutional theory is to indicate how successful a firm's business model is [9]. While the combination of elements of these three theories in research on BM reporting emphasizes the importance of this area. Conflicts and problems appear on the line-goals and intentions of the enterprise-needs of stakeholders, compliance with legal regulations and standards, and the occurring tendencies to increase disclosures about the enterprise.

Communication by enterprises to stakeholders contains certain information about the enterprise. Examples include the following: environmental aspects (CSR), corporate governance, and risk management [24-30], and many other non-financial areas, inter alia intangible assets and intellectual capital [13]. The narrow approach to reporting drew attention to the dynamics of processes and the ability of entities to integrate, create, and transform internal and external competences to respond to the changing environment [2]. These in turn reflect in the design of BM and its reporting.

Despite the influence of action-intentionalism, the usefulness of reporting in the process of communicating about the BM is emphasized by many researchers and institutions $[9,16]$. Additionally, there is a mention of the term "Business Model Disclosure", which aims to provide information on a BM that is not supplied through traditional financial reports [31].

The development of the reporting spectrum has resulted in initiatives that attempt to integrate it to achieve consistency while maintaining the principle of true and fair views [32]. On 9 December 2013, the International Integrated Reporting Council issued recommendations on the Integrated Reporting Framework, which was the first international attempt to consolidate business reporting [10]. From this perspective, integrated reporting provides "a process founded on integrated thinking that results in a periodic integrated report by an organization about value creation over time and related communications" [10]. It takes the form of an integrated report which is "concise communication about how an organization's strategy, governance, performance and prospects, in the context of its external environment, lead to the creation of value in the short, medium and long term" [10]. The initiators' intention to clearly separate such a report was to focus on many aspects (financial, ecological, human) originally presented in multiple reports accompanying financial reports, and to concentrate largely on non-financial information [33-36]. This may also be recognized as a reflection of following the mainstream of stakeholder theory and increasing its role in shaping corporate reporting. Integrated reporting that combines financial and non-financial information into one document is a significant evolutionary step towards creating an advanced sustainability reporting tool [37].

As a result of the development of integrated reporting, reporting is moving away from a traditional, synthetic system, supplemented only with selective verbal description, in the direction of extended information on the process of creating value. However, the premise of 
integrated reporting is always to present companies' business models in a holistic way [1]. Given the considerable diversity of practical approaches, the authors suggest considering integrated reporting from a broader perspective, which covers various reports (financial, CSR, non-financial and integrated reports).

Consequently, the International Accounting Standards Board (IASB) and International Integrated Reporting Council (IIRC) indicate that communication about the BM is one of the stages of reporting evolution, which resulted, for instance, in the integrated report [31]. Simultaneously, due to the lack of specific guidelines, BM disclosures is "inconsistent, incomparable, and incomplete" and takes the form of a boilerplate; rather generalised [16,38].

Approximately only $40 \%$ of reporting on the BM provided in-depth and detailed information about the issue, and only $8 \%$ of BM disclosures combined these data with reporting on the strategy and business risks [16]. Moreover, the current state of research on the BM is not advanced from the perspective of implementing the information and the reporting function of accounting. Studies on business models are not extensive [1,39], while researchers emphasise the need to strengthen these studies, both in the epistemological and empirical layers $[40,41]$. This is directly related to the fact that enterprises today often create value in a complex manner that cannot be demonstrated solely on the basis of traditional financial reporting based on assets or cash flows. Page's research [38] showed a high degree of generalisation of the presented disclosures of the BM. However, Lai et al. [31] obtained opposite results in European early adopters. These researchers revealed that the entities disclose the BM in a broad and detailed way (inputs, business activity, outputs and outcomes), including information about six different forms of capital presented in an extensive and balanced manner. Importantly, these studies showed a predominance of the descriptive nature of reporting, while the quantitative dimension was significantly limited. Malola and Maroun [42] show that companies with higher quality integrated reports are those that invest in complementing their integrated reports with a sustainability report and have their disclosures externally assured.

Bearing in mind the current, fragmentary research results of other researchers, the authors identified a research gap in the form of a lack of in-depth research on BM disclosures, particularly in European early adopter countries. This gap also focuses on the development of BM disclosure provided by listed companies and its relations with a specific set of components, as well as the observation of these relations' trends over a longer period of time. This seems to be especially interesting from the perspective of initial research on the relationship between BM and accounting.

\subsection{Business Model Reporting in Selected Companies}

Given the short implementation period, it should be emphasized that empirical research into integrated reporting, particularly into BM disclosures in corporate reporting, is very rare $[43,44]$. It is difficult to clearly distinguish the sectors in which these studies dominate, but certain foundations and results can be taken from much broader environmental reporting, including CSR, which is strongly developed in energy, fuel, mining, high-technology and banking sector. The companies representing these sectors must meet the expectations of many different groups of stakeholders, in particular: society, local governments and communities, organizations and bodies for environmental protection, as well as the additional legal regulations and environmental requirements. They not only undertake numerous social and environmental activities but must also report on them. These activities are inseparable from the assumptions of stakeholder theory and legitimacy theory. They are also a way of building a positive image for the company within the society.

Few studies examine BM disclosures in mining entities. Evidence from the UK indicates that these companies present a selective and soft approach to sustainability in the context of mandatory disclosure about the BM. Researchers indicate that entities present the full value chain in the reporting process (mining operations, processing and sales), and there is a tendency to introduce their own indicators dedicated to the environmental dimension [45]. Each entity uses a different approach to disclose information [46], 
which can be interpreted as a significant degree of individualisation of reporting processes being implemented.

The issues of environmental impact and relations with the local community as well as working conditions are discussed quite often. However, initiatives in other areas are overlooked. Topics such as the use of raw materials or information on waste are ignored or marginally presented; in turn, human rights, recruitment and training are only demonstrated in a descriptive way [47]. Perez and Sachez [46] indicated that the biggest entities in the mining industry produced more comprehensive and sophisticated reports. Additionally, research has confirmed the reluctance to disclose a wide spectrum of information beyond the particulars required by legal regulations $[48,49]$. Therefore, it can be considered that the quality and scope of disclosures are strongly determined by the applicable reporting standards, which underlines the important influence of institutional theory.

Further, research from the UK listed entities operating in high-technology industries, and their BM disclosures in the strategic report indicated that only a few companies use the $\mathrm{BM}$ to emphasize the process of creating and capturing value. Moreover, the BM is often not clearly distinguished and poorly illustrates the interactions among its components [50]. The scope of disclosed information in integrated reports may also be affected by the financial performance of entities [32]. Enterprises with lower financial performance tend to produce longer, more complex and less readable reports [51]. The purpose of such a behaviour may be to "window-dress" real causes and divert the attention of stakeholders towards soft discretionary disclosures [52].

The results of empirical research on integrated reports in Poland are also few and in the early stages of development. These reports are prepared by a few entities listed on the Warsaw Stock Exchange (in the years 2013-2016, there were only 12 entities and less than 30 reports) [53]. Despite these limitations, studies confirmed the descriptive nature of these reports and the predominance of presenting non-financial content over financial content. The BM in the reporting of Polish enterprises is not subject to explicit and broad distinction. Moreover, only a few enterprises used the boilerplate structure indicated by IIRC, although they tried to refer to almost all components of the BM, but in a non-uniform manner [54]. Despite this, many BM elements are disclosed. Moreover, the areas of disclosure are significantly random, and as a result, there is no clear combination of these components and no indication of the path of value creation [55]. Certainly, this limits the cognitive function that the BM should fulfil. The Polish enterprises focused on the following BM components: objectives and strategy, presentation of capital in accordance with the IIRC concept, products, labour-related matters, waste, and emissions and the results of operations which were reflected by disclosing the key performance indicators (KPIs) [54-56]. This subject underwent a minor transformation, as prior research indicated that the entities had focused on the presentation of objectives and strategies, although they did not include the subject of value creation, relations with customers or other stakeholders [57]. Reporting on capital as a component of the BM is also developing $[54,56]$. However, throughout these years, the incompleteness, inconsistency, the dispersive nature of the information presented and even misunderstanding the essence of the BM were still emphasized.

Based on the above-mentioned research, it should be noted that entities may experience trials and errors in the process of integrated reporting as it is a relatively new concept, and the process of full presentation of all elements of a BM can take several years to be fully developed [58]. Relying on institutional theory [23], it can be noticed that the reporting patterns of enterprises are adjusted to existing regulations, although the process is not clear. It should be noted, however, that the reason may be the level of detail of these regulations. This occurs in Poland, where the regulations on disclosure of the BM are very general. Garcia-Sánchez et al. [59] also described the impact of national cultural systems on integrated reporting, while Frías-Aceituno et al. [60] analysed the impact of legal systems on integrated reporting. Research carried out in South Africa provides empirical evidence for the impact of the regulatory environment on integrated reporting [61]. The gap between 
current company reporting practices and integrated reporting framework requirements was also studied [61,62].

On the other hand, looking at this process from a broader perspective [63], organizations try to change management behaviour and disclose more information highlighting efforts to adhere to socially acceptable norms and values in order to change stakeholder views. External incentives applied to the perception of the principles of sustainable development cause organizations belonging to the same industry to follow the industry leader's reporting patterns so as to gain greater legitimacy from the public. Such practices favour the process of institutionalizing reporting practices, especially in sectors that are particularly socially vulnerable.

One can conclude that the above-described phenomena occur in companies that prepare integrated reports; however, it can also be inferred that the situation is much more complicated in companies that do not prepare such reports. Based on the assumptions of institutional theory, it can be assumed that more detailed legal regulations and additional reporting standards extend the reporting horizon. This also applies to the BM and its embedding in integrated reporting. The above justifies the advancement of the first research hypothesis:

Hypothesis 1 (H1). It is assumed that enterprises that prepare integrated reports provide more detailed disclosures about their activities and business model compared to enterprises that do not prepare such reports.

The BM is often depicted in graphic form [55,62]. Some authors believe that in order to present the holistic and multi-faceted dimensions of a BM, information about it must be conveyed through a story that can be expressed in various forms. The purpose of such a solution is, on the one hand, to legitimize various economic, social and environmental activities conducted by an enterprise, and at the same time, to satisfy the needs of a very diverse group of stakeholders. Many additional elements, covering company background, non-financial and forward-looking information, are largely reported in a narrative form [13]. Companies also use diagrams to illustrate their BM in a descriptive form and to distinguish how they create value. According to researchers, BM components are an indistinct factor in determining differences between business models, but when combined they present the path leading to value creation [64]. Perhaps the use of diagrams and illustrations, as well as their presentation in interactive form on websites is the reason why researchers indicate limited numbers of integrated reports [54]. The intention of the presented study was to compare the two groups of information: financial (numerical) and non-financial. With the aim of expanding the results of existing studies, the following hypothesis was advanced:

Hypothesis $2 \mathbf{( H 2 ) . ~ I t ~ i s ~ a s s u m e d ~ t h a t ~ e n t e r p r i s e s ~ w h i c h ~ u s e ~ i n t e g r a t e d ~ r e p o r t i n g ~ t e n d ~ t o ~ d i s c l o s e ~}$ more descriptive information about selected non-financial components of their business model than financial (numerical) information.

\subsection{Reporting on Business Model and Economic Parameters of Enterprises}

The academic literature presents different studies on the relationship between disclosures and selected economic parameters of an enterprise. These studies do not relate specifically to disclosures about the BM but to the selected economic parameters as well as to many different characteristics (i.e., market attributes). Hence, they form a backdrop to our study. Ohlson [65] examined the differences in compliance of book values and profits between two groups of firms using the developed valuation model. More transparent disclosures increase the overall reliability of financial statements, which increases decision-making usability for investors. This view is in line with theoretical assumptions that suggest that higher quality disclosures resulting in higher information precision have a greater impact on share prices. Assuming that the errors in the measurement of book values cause the regression coefficients to be oriented towards zero, it can be expected that such coefficients decrease as the transparency of disclosures decrease. Verrecchia [66] shows that 
the coefficient that measures the market's response to a disclosure is a growing function of the quality (precision) of disclosure. Clearer, and therefore higher quality, disclosures enable investors to better interpret the consequences of aggregated approaches. Research also suggests that investors find more detailed and transparent disclosures more useful in decision-making [65]. Jensen and Berg [67] examined country-based characteristics impacting the decisions of companies to publish integrated reports. Rivera-Arrubla et al. [68] analysed the influence of company-level determinants (i.e., GRI application level, publication of the report on the IIRC website and length of the report, industry and auditor type, external assurance of the report,) on disclosures in integrated reports.

Research carried out by Dratwińska-Kania [69] on a group of investment funds in Poland confirms the correlation between the level of transparency on the condition of the investment fund operations account and selected characteristic features for a selected group of funds (e.g., a change in the value of participation units). The literature indicates that profitable enterprises voluntarily show more detailed environmental disclosures so as to promote their activities [70,71]. The same applies to their BM. In turn, Cowen et al. [72] and Patten [73] found no relationship between profit and disclosed information, while Roberts [71] found links between disclosures of social and environmental data and good financial results, measured by return on capital.

Considering the taxonomy of BM components used in the literature, it was found that increasing disclosures about specific components increases the quality and development of reporting on the BM [31]. On this basis, we assume that larger, more developed companies reveal more details about their business model, also to fulfil legitimization processes. The parameters that characterize these enterprises are board members, total assets, equity, performance, EBITda and liabilities). To this end, another detailed hypothesis is advanced:

Hypothesis 3 (H3). It is assumed that there are positive correlations between the amount of disclosed information about the business model and the results achieved for specific economic parameters that characterize the enterprise.

The overall goal of the study is to expand research on disclosures about the BM in corporate reporting, as well as to indicate the degree and directions of development of this subject against the background of the accounting system.

The detailed aim is to investigate the number of disclosures on selected components of the BM, as well as the division of this information into financial (numerical) and nonfinancial (descriptive) form. The second detailed aim is to examine the correlation between the business model's components and selected company's parameters including total assets, performance, board, earnings before interest and taxes (EBITda), equity and liabilities.

\section{Materials and Methods}

To attain the indicated goals and verify the hypotheses, the study covered financial statements and similar reports for 2017, 2018 and 2019 (96 observations), issued by 32 randomly selected enterprises from 5 selected industries (listed on the Warsaw Stock Exchange, on the following indices: WIG-Energy, WIG-Fuels, WIG-Mining, WIG-Telecommunications and WIG-Banks). The types of reports covered by the study are presented in Table 1.

Within the group of 32 companies, only 9 issued an integrated report. It should be emphasized that the relatively small research sample is conditioned by the small number of enterprises that currently publish information about their BM. Information on the BM is derived from different reports, as there is no single unified reporting concept regarding this issue; however, authors tried to focus on integrated reports. 
Table 1. Types of reports examined in the field of disclosures about the business model in the companies studied.

\begin{tabular}{|c|c|c|}
\hline Industry & Enterprise Name & Type of Report \\
\hline Energetics & ENEA & CR, MR, N-FR \\
\hline Energetics & Tauron & $\mathrm{IR}, \mathrm{MR}$ \\
\hline Energetics & Kogeneracja & $\mathrm{CR}, \mathrm{MR}$ \\
\hline Energetics & Zepak & $\mathrm{CR}, \mathrm{MR}$ \\
\hline Energetics & Polenergia & CR, MR, CSR \\
\hline Energetics & PGE & $\mathrm{IR}, \mathrm{CR}, \mathrm{MR}$ \\
\hline Energetics & Energa & CR, MR, CSR \\
\hline Energetics & MLSystem & $\mathrm{CR}, \mathrm{MR}$ \\
\hline Energetics & Będzin & $\mathrm{CR}, \mathrm{MR}$ \\
\hline Mining & Bogdanka & IR, CR, MR \\
\hline Mining & JSW & CR, MR, N-FR \\
\hline Mining & KGHM & IR, CR, MR, N-FR \\
\hline Fuel & Lotos & $\mathrm{IR}, \mathrm{CR}, \mathrm{MR}$ \\
\hline Fuel & Orlen & $\mathrm{IR}, \mathrm{CR}, \mathrm{MR}$ \\
\hline Fuel & PGNIG & CR, MR, N-FR \\
\hline Fuel & SKOTAN & CR, MR, N-FR \\
\hline Fuel & UNIMOT & $\mathrm{CR}, \mathrm{MR}$ \\
\hline Telecommunications & Orange & IR, CR \\
\hline Telecommunications & Netia & CR, N-FR \\
\hline Telecommunications & Cyfrowy Polsat & MR, N-FR \\
\hline Banks & INGBSK & IR, CR, MR, N-FR \\
\hline Banks & Getin Holding & $\mathrm{CR}, \mathrm{MR}$ \\
\hline Banks & Getin Noble & CR, MR, N-FR \\
\hline Banks & BOS & $\mathrm{CR}, \mathrm{MR}, \mathrm{CSR}$ \\
\hline Banks & Alior & CR, MR, N-FR \\
\hline Banks & Millenium & CR, MR, N-FR \\
\hline
\end{tabular}

Explanation: Integrated Report (IR); Consolidated report (CR); Management report (MR); Non-financial data report (N-FR); Corporate Social Responsibility Report (CSR).

This study complements and extends the research carried out by Dratwińska-Kania et al. [74]. With the aim of selecting a representation of IR adopters, the research sample was gathered from the official Integrated Reporting Example Database, which includes companies from the Polish "IR Reporters", the WIG Index 30 (30 companies) and the Respect Index (31 companies).

The industry comparison made by the authors showed that the largest number of companies that prepare integrated reports belong to the aforementioned five industry sectors: WIG-Energy, WIG-Fuels, WIG-Mining, WIG-Telecommunications and WIG-Banks. In addition, the authors chose the sectors WIG-Energy, WIG-Fuels and WIG-Mining because environment-enterprise relationships are visible in every section of the value chain, which is why these companies have particularly strongly developed reporting on corporate social responsibility (CSR). Energy, fuel and mining companies are required to conduct sustainable activities aimed at maintaining the sustainability of land, air and water resources, meeting the expectations of various stakeholder groups. Enterprises from these industries perform tasks in line with many environmental regulations, consisting of the implementation of activities for the benefit of society and the environment, financed from own resources. By preparing CSR environmental reports and engaging the media, such firms help to raise social awareness, and thus, such activities are inseparable from the assumptions of stakeholder theory. The use of CSR reporting on the BM in such companies leads to believe that the business models in these companies will be more sophisticated and advanced, which enhances the credibility of the research results obtained.

Enterprises from the telecommunications industry were included in the research sample, as the transformations of the BM in this sector are particularly profound due to the rapid development of new technologies and high competitiveness among service providers. These enterprises need to create appropriate security systems related to cyberspace. An 
appropriate $\mathrm{BM}$ enables understanding of business logic and the infrastructure necessary to operationalize this concept [41].

Banks are a type of organization, which, due to the diversification of the research group, can make the results more attractive and enriched. Banks are public trust institutions and are subject to specific regulatory requirements and consequently the detail and quality of reporting in such institutions is very high and more evolved than in other sectors. The findings presented by Mechelli et al. [75] imply that companies belonging to the financial services sector, due to their high public accountability and strong interaction with customers, present the most strategy-related disclosure. Results provided by Zijl et al. [76] also confirm that banks provide the most information on their strategy and that they dominate in the ranking in terms of providing social strategy and economic strategy disclosure. However, the degree of environmental disclosure was a little lower, which is understandable given these companies' specialization. To counter this, banks may inform stakeholders about funding clean energy projects [76], their use of natural resources or other ecological activities. On the other hand, studies by Ungerer [77] and Sukhari and De Villiers [78] showed that companies from the energy and mining sectors made more disclosure about strategy than banks. Moreover, results presented by Mohammad [79] demonstrate that banks provide little holistic, integrated information on the economic, environmental and social aspects of business without this being linked to financial information. Therefore, it can be concluded that banks fulfil the assumptions of the stakeholder theory, even though they selectively pursue reporting objectives.

The studied relationship between the amount of information about the BM disclosed as part of the adopted components and selected economic parameters comprised two levels of analysis: performing a manual content analysis and a multivariate statistical analysis. The study consisted of gathering information disclosed by selected enterprises under the four main components of the BM. For this purpose, the disclosure map proposed by CIMA and IIRC $[7,13]$ was used, according to which the BM consists of 4 components:

1. Inputs, which include the following capitals: financial, manufactured, human, intellectual, natural, social and relationship.

2. Business activities, which include such categories as: planning, design, production, training, research and development, innovation and relationship management.

3. Outputs (output effects), including key products, key services, waste and other by-products.

4. Outcomes, including such categories as: customer satisfaction, profit/loss, shareholder return, asset consumption, employment creation, employee development and commitment, improvement of living standards, environmental impact, licenses/certificates and contribution to the local economy.

As part of the indicated components, 26 detailed disclosures were identified in 2017, 2018 and 2019. In the first stage of the analysis, the total number of disclosures (financial and non-financial) about the BM for each company was examined. The descriptive form of the specified disclosures was also studied in this stage of the research. For each of the selected descriptive parameters, the following points were given: 1 , when the information was disclosed, and 0 , when there were no such disclosures. As a result, the maximum number of points that could be awarded for an enterprise was 52 for one year (26 descriptive disclosures and 26 financial disclosures) and 156 in total for all the years analysed. The research was based on content analysis, an empirically important research tool in the field of social and environmental reporting, intellectual capital reporting and integrated reporting $[80,81]$.

The purpose of this stage was to compare the disclosures of companies that prepare a non-financial report and those that do not. The second stage of the study was to collect information on individual components of the BM in total values and to separate out only the financial information. The purpose of this part of the research, apart from presenting disclosures about the BM, was to compare the published disclosures about financial and non-financial information. 
As part of the study on the interdependence of specific BM components, the correlation between the sum of disclosures about the BM in selected components for the studied enterprises and selected economic parameters achieved by these entities for 2017, 2018 and 2019 were examined. The analysed economic parameters included board (number of members), total assets, equity, performance, EBITda and liabilities.

The board has greater motivation to increase the value of an enterprise because it increases the value of the assets they manage and allows them to achieve management goals. Donnelly and Mulcahy [82] reported clear evidence that voluntary disclosure increases with the number of non-executive directors on the board. Firms that have a non-executive chairman make greater voluntary disclosures than other firms. Samaha, Khlif and Hussainey [83] came to a similar conclusion in their research and found that board size has a significant positive effect on voluntary disclosure. The presence of a larger number of board members who take care of the interests of various stakeholder groups should stimulate an increase in the disclosure of information. This is in line with stakeholder theory that requires a higher level of disclosure, indicating the compliance of the objectives of various stakeholders. Such an assumption is consistent with research by Manes-Rossi [84], who examined the presence of external members on boards. The effect of board characteristics on integrated reporting quality according to the agency theory approach was researched by Vitolla et al. [85]. The findings, based on a sample of 134 international firms, show a positive relationship between the size, independence, diversity and activity of a board, and the quality of integrated reporting. Gandía [86] highlights how a board made up of a larger number of members favours the effectiveness and efficiency of such functions, consequently increasing both the level of transparency of the company and the disclosure of information by top management.

However, a few researchers found an inverse relationship [87,88]. Empirical findings from Pearson correlation analysis show that there is a negative correlation between board size (proxied as the number of board members) and the level of corporate environmental disclosure among the selected firms [87].

Firm size is considered as an important factor to determine the levels of disclosures [89]. There is a correlation between the size of the enterprise and the scope of its disclosures. This is also confirmed by agency theory, which suggests that "big firms have higher agency costs than small firms". To reduce this agency cost, large firms adopt more extensive and comprehensive disclosures [90]. The size of an enterprise can be measured by the size of assets (total assets) as well as equity. Performance and EBITda are measures of assessing an enterprise's profitability. It is assumed that profitable enterprises have an incentive to present themselves in a better light and in a more detailed manner than less profitable ones in order to raise capital on the best available terms.

Enterprises with a high level of liabilities have increased disclosure needs to meet the security of lenders and confirm their ability to generate further debt.

Statistical correlation analysis in the presented study was based on Spearman's. The arguments for using this coefficient were the small sample size (32 companies) and the fact that qualitative and quantitative data were compared. As the data are cross-sectional, it is possible to unambiguously organize them from the smallest to the largest and assign ranks. In the case of two or more identical values, the standard tied ranks are used. Notably, for the analysis tool adopted, the study does not analyse curvilinear dependencies which would require a coefficient that takes into account the lack of monotonicity of the variables [91], pp. 742-746.

Nevertheless, in addition to increasing the reliability of the research results, it was examined whether the data on reporting disclosures were normally distributed. The Shapiro-Wilk test appropriate for small samples $(n=32)$ was used.

The conducted research shows that the distribution of disclosure data does not have a distribution close to the normal distribution. The use of the Spearman's rank method to test the strength of the relationship between the number of disclosures and other reporting data is therefore justified. 
The significance coefficient for the examined variables was set to $p=0.05$, and the critical area was determined in the form: $<-1,-0.3493>$ or $<0.3493,1>$.

The basic research limitations include:

- $\quad$ Conducting the survey on a sample of 32 enterprises;

- $\quad$ The short period of reported data (3 years);

- $\quad$ Focusing on one country;

- $\quad$ The audit is based on subjective information that companies publish about themselves and that is not subject to audit by a statutory auditor.

Future research on an enlarged sample of companies from other EU countries may provide valuable information on the level of disclosure on the BM and regulatory challenges required to meet stakeholder expectations. Research extended by subsequent years of disclosures about the BM can provide information about changes in the studied patterns over time.

\section{Results}

Research on the number of disclosures about BM in surveyed companies indicate that the enterprises that prepared an integrated report (enterprises in colour in the following Table 2) are characterized by a greater number of disclosures about the BM than those that do not prepare such report.

Table 2 shows that the total number of disclosures for enterprises preparing the integrated report in 2019, 2018 and 2017 was above 70 points, with the exception of Lotos (67-68 disclosures recorded within the surveyed period), mBank (47 disclosures in each surveyed year) and INGBSK $(45,44,44$, respectively). Banks do not dominate this area of reporting. The total numbers of BM disclosures for banks are usually lower than for enterprises from the non-financial sector. Moreover, in the group of enterprises not compiling an integrated report, the number of disclosures about the BM is usually smaller, except Netia and Cyfrowy Polsat, which are the only companies from this group that exceeded 70 disclosures.

The differences in the number of disclosures about the BM in these two groups of enterprises apply to all analysed components (inputs, business activities, outputs, outcomes) to a similar degree. In addition, during the content analysis of reports in terms of disclosures about the BM, it was found that the description of the BM of enterprises preparing the integrated report is more comprehensive and clearer. The reverse relationship was also true; the information on the BM of the enterprises that did not prepare an integrated report often had to be found in other reports. The group of enterprises that did not prepare an integrated report is also characterized by the fact that some components of the BM were not disclosed in individual cases (in companies: ENEA, Kogeneracja, or Polenergia, BHW).

The entire research sample is set apart by the fact that the information highlighted in the components of the BM was approximately the same in 2017, 2018 and 2019. This is reflected in the scoring of individual components (Table 2).

The data presented in the four sections of the main components (inputs, business activities, outputs, outcomes) are presented in two reporting dimensions. The first concerns the financial and non-financial dimensions (e.g., inputs), the second concerns disclosures in the financial dimension only (e.g., inputs-only financial information).

To sum up the disclosures about the BM, it should be noted that there are many of these disclosures and that most of the analysed enterprises generate elaborated information about the BM but in many different parts of reports. It was also found that banks disclose the least detailed information about their BM from among the companies in the group studied.

The next stage of the study was an in-depth analysis of the content and substance of detailed elements of BM components for all enterprises surveyed in an integrated manner as well as separate information on financial (numerical) disclosures (Table 3). 
Table 2. Number of disclosures about the business model in economic categories in surveyed companies. ${ }^{1}$

\begin{tabular}{|c|c|c|c|c|c|c|c|c|c|c|c|c|c|c|c|c|c|c|c|c|c|c|c|c|c|c|c|}
\hline \multirow[t]{2}{*}{ Company } & \multicolumn{3}{|c|}{ Inputs } & \multicolumn{3}{|c|}{$\begin{array}{l}\text { Inputs-Only } \\
\text { Financial Information }\end{array}$} & \multicolumn{3}{|c|}{ Business Activities } & \multicolumn{3}{|c|}{$\begin{array}{c}\text { Business } \\
\text { Activities-Only } \\
\text { Financial Information }\end{array}$} & \multicolumn{3}{|c|}{ Outputs } & \multicolumn{3}{|c|}{$\begin{array}{l}\text { Outputs-Only } \\
\text { Financial Information }\end{array}$} & \multicolumn{3}{|c|}{ Outcomes } & \multicolumn{3}{|c|}{$\begin{array}{l}\text { Outcomes-Only } \\
\text { Financial Information }\end{array}$} & \multicolumn{3}{|c|}{ Total } \\
\hline & 2019 & 2018 & 2017 & 2019 & 2018 & 2017 & 2019 & 2018 & 2017 & 2019 & 2018 & 2017 & 2019 & 2018 & 2017 & 2019 & 2018 & 2017 & 2019 & 2018 & 2017 & 2019 & 2018 & 2017 & 2019 & 2018 & 2017 \\
\hline ENEA & 7 & 9 & 8 & 2 & 3 & 3 & 9 & 9 & 10 & 3 & 3 & 4 & 6 & 6 & 6 & 2 & 2 & 2 & 19 & 19 & 19 & 9 & 9 & 9 & 57 & 60 & 61 \\
\hline TAURON & 11 & 11 & 11 & 6 & 6 & 6 & 12 & 12 & 12 & 6 & 6 & 6 & 8 & 8 & 8 & 4 & 4 & 4 & 20 & 19 & 19 & 10 & 9 & 9 & 77 & 75 & 75 \\
\hline KOGENERACJA & 8 & 4 & 4 & 3 & 2 & 2 & 12 & 6 & 6 & 6 & 1 & 1 & 7 & 3 & 3 & 3 & 1 & 1 & 18 & 7 & 7 & 8 & 2 & 2 & 65 & 26 & 26 \\
\hline ZEPAK & 11 & 9 & 9 & 6 & 5 & 5 & 11 & 12 & 10 & 5 & 6 & 5 & 6 & 6 & 6 & 2 & 2 & 2 & 18 & 14 & 14 & 8 & 6 & 6 & 67 & 60 & 57 \\
\hline POLENERGIA & 10 & 11 & 11 & 5 & 6 & 6 & 10 & 11 & 11 & 5 & 5 & 5 & 1 & 1 & 1 & 0 & 0 & 0 & 5 & 2 & 2 & 2 & 0 & 0 & 38 & 36 & 36 \\
\hline PGE & 11 & 11 & 11 & 6 & 6 & 6 & 12 & 12 & 12 & 6 & 6 & 6 & 8 & 8 & 8 & 4 & 4 & 4 & 20 & 20 & 20 & 10 & 10 & 10 & 77 & 77 & 77 \\
\hline ML SYSTEM & 10 & 9 & 9 & 4 & 4 & 4 & 12 & 12 & 12 & 6 & 6 & 6 & 4 & 4 & 4 & 2 & 2 & 2 & 18 & 18 & 18 & 9 & 9 & 9 & 65 & 64 & 64 \\
\hline BĘDZIN & 8 & 8 & 8 & 3 & 3 & 3 & 8 & 6 & 6 & 3 & 1 & 1 & 6 & 5 & 5 & 2 & 2 & 2 & 14 & 11 & 11 & 6 & 3 & 3 & 50 & 39 & 39 \\
\hline BOGDANKA & 11 & 11 & 11 & 6 & 6 & 6 & 12 & 12 & 12 & 6 & 6 & 6 & 8 & 8 & 8 & 4 & 4 & 4 & 20 & 20 & 20 & 10 & 10 & 10 & 77 & 77 & 77 \\
\hline JSW & 11 & 11 & 11 & 6 & 6 & 6 & 12 & 12 & 12 & 6 & 6 & 6 & 8 & 8 & 8 & 4 & 4 & 4 & 20 & 20 & 20 & 10 & 10 & 10 & 77 & 77 & 77 \\
\hline KGHM & 11 & 11 & 11 & 6 & 6 & 6 & 12 & 12 & 12 & 6 & 6 & 6 & 8 & 8 & 8 & 4 & 4 & 4 & 18 & 19 & 19 & 8 & 9 & 9 & 73 & 75 & 75 \\
\hline LOTOS & 9 & 8 & 8 & 3 & 2 & 2 & 12 & 12 & 12 & 6 & 6 & 6 & 6 & 8 & 8 & 2 & 4 & 4 & 19 & 19 & 19 & 10 & 9 & 9 & 67 & 68 & 68 \\
\hline ORLEN & 11 & 11 & 11 & 6 & 6 & 6 & 12 & 12 & 12 & 6 & 6 & 6 & 8 & 8 & 8 & 4 & 4 & 4 & 20 & 20 & 20 & 10 & 10 & 10 & 77 & 77 & 77 \\
\hline PGNIG & 11 & 11 & 11 & 6 & 6 & 6 & 12 & 12 & 12 & 6 & 6 & 6 & 8 & 8 & 8 & 4 & 4 & 4 & 20 & 20 & 20 & 10 & 10 & 10 & 77 & 77 & 77 \\
\hline SKOTAN & 6 & 6 & 6 & 3 & 3 & 3 & 6 & 6 & 6 & 2 & 2 & 2 & 4 & 4 & 4 & 2 & 2 & 2 & 12 & 12 & 12 & 4 & 4 & 4 & 39 & 39 & 39 \\
\hline UNIMOT & 5 & 5 & 5 & 2 & 2 & 2 & 8 & 8 & 8 & 4 & 4 & 4 & 4 & 4 & 4 & 2 & 2 & 2 & 14 & 14 & 14 & 7 & 7 & 7 & 46 & 46 & 46 \\
\hline NETIA & 11 & 11 & 11 & 6 & 6 & 6 & 6 & 8 & 9 & 2 & 2 & 3 & 6 & 6 & 6 & 2 & 2 & 2 & 14 & 14 & 14 & 4 & 4 & 4 & 51 & 53 & 55 \\
\hline CYFR.POLSAT & 10 & 11 & 11 & 5 & 6 & 6 & 12 & 12 & 12 & 6 & 6 & 6 & 8 & 8 & 8 & 4 & 4 & 4 & 20 & 20 & 20 & 10 & 10 & 10 & 75 & 77 & 77 \\
\hline INGBSK & 8 & 8 & 8 & 3 & 2 & 2 & 8 & 8 & 8 & 2 & 2 & 2 & 5 & 5 & 5 & 2 & 2 & 2 & 13 & 13 & 13 & 4 & 4 & 4 & 45 & 44 & 44 \\
\hline GETIN HOLDING & 7 & 7 & 5 & 1 & 1 & 1 & 7 & 7 & 7 & 1 & 1 & 1 & 5 & 5 & 5 & 2 & 2 & 2 & 10 & 10 & 10 & 1 & 1 & 1 & 34 & 34 & 32 \\
\hline GETIN NOBLE & 5 & 5 & 5 & 1 & 1 & 1 & 7 & 7 & 7 & 1 & 1 & 1 & 5 & 5 & 5 & 2 & 2 & 2 & 9 & 9 & 9 & 2 & 2 & 2 & 32 & 32 & 32 \\
\hline BOS & 8 & 7 & 7 & 2 & 2 & 2 & 9 & 9 & 8 & 3 & 3 & 2 & 5 & 5 & 5 & 2 & 2 & 2 & 11 & 11 & 11 & 3 & 3 & 3 & 43 & 42 & 40 \\
\hline Alior & 6 & 6 & 6 & 1 & 1 & 1 & 8 & 8 & 10 & 2 & 2 & 4 & 5 & 5 & 5 & 2 & 2 & 2 & 13 & 13 & 13 & 4 & 4 & 4 & 41 & 41 & 45 \\
\hline Millenium & 9 & 9 & 9 & 3 & 3 & 3 & 8 & 8 & 8 & 2 & 2 & 2 & 5 & 5 & 5 & 2 & 2 & 2 & 14 & 14 & 14 & 5 & 5 & 5 & 48 & 48 & 48 \\
\hline BNP Paribas & 7 & 7 & 7 & 1 & 1 & 1 & 8 & 8 & 8 & 2 & 2 & 2 & 4 & 4 & 4 & 2 & 2 & 2 & 16 & 16 & 16 & 6 & 6 & 6 & 46 & 46 & 46 \\
\hline BHW & 6 & 6 & 6 & 0 & 0 & 0 & 6 & 6 & 6 & 0 & 0 & 0 & 5 & 5 & 5 & 2 & 2 & 2 & 11 & 11 & 11 & 2 & 2 & 2 & 32 & 32 & 32 \\
\hline mBank & 7 & 7 & 7 & 1 & 1 & 1 & 9 & 9 & 9 & 3 & 3 & 3 & 5 & 5 & 5 & 2 & 2 & 2 & 15 & 15 & 15 & 5 & 5 & 5 & 47 & 47 & 47 \\
\hline PEKAO & 7 & 7 & 7 & 2 & 2 & 2 & 8 & 8 & 8 & 2 & 2 & 2 & 4 & 4 & 4 & 2 & 2 & 2 & 16 & 16 & 16 & 7 & 7 & 7 & 48 & 48 & 48 \\
\hline PKO & 8 & 8 & 8 & 2 & 2 & 2 & 9 & 9 & 9 & 3 & 3 & 3 & 7 & 7 & 7 & 3 & 3 & 3 & 16 & 16 & 16 & 6 & 6 & 6 & 54 & 54 & 54 \\
\hline SANTANDER & 9 & 9 & 9 & 3 & 3 & 3 & 8 & 8 & 8 & 2 & 2 & 2 & 4 & 4 & 4 & 2 & 2 & 2 & 13 & 13 & 13 & 3 & 3 & 3 & 44 & 44 & 44 \\
\hline Total & 279 & 274 & 271 & 114 & 113 & 113 & 309 & 305 & 306 & 125 & 119 & 121 & 189 & 186 & 186 & 84 & 84 & 84 & 505 & 483 & 483 & 212 & 197 & 197 & 1817 & 1761 & 1761 \\
\hline
\end{tabular}


Table 3. Number of disclosures about the business model in the surveyed companies.

\begin{tabular}{|c|c|c|c|c|c|c|c|c|c|}
\hline \multirow{3}{*}{ Disclosure } & \multicolumn{3}{|c|}{2019} & \multicolumn{3}{|c|}{2018} & \multicolumn{3}{|c|}{2017} \\
\hline & \multirow{2}{*}{ Total } & \multicolumn{2}{|c|}{ Only Financial Information } & \multirow{2}{*}{ Total } & \multicolumn{2}{|c|}{ Only Financial Information } & \multirow{2}{*}{ Total } & \multicolumn{2}{|c|}{ Only Financial Information } \\
\hline & & In Number & $\%$ Total & & In Number & $\%$ Total & & In Number & $\%$ Total \\
\hline \multicolumn{10}{|c|}{ INPUTS } \\
\hline Financial capital & 62 & 30 & 48.4 & 58 & 28 & 48.3 & 58 & 28 & 48.3 \\
\hline Manufactured capital & 52 & 20 & 38.5 & 53 & 21 & 39.6 & 52 & 21 & 40.4 \\
\hline Human capital & 50 & 19 & 38.0 & 49 & 18 & 36.7 & 49 & 18 & 36.7 \\
\hline Intellectual capital & 43 & 15 & 34.9 & 42 & 16 & 38.1 & 41 & 16 & 39.0 \\
\hline Social and relationship capital & 44 & 14 & 31.8 & 44 & 15 & 34.1 & 44 & 15 & 34.1 \\
\hline Total inputs & 295 & 114 & 38.6 & 289 & 113 & 39.1 & 286 & 113 & 39.5 \\
\hline \multicolumn{10}{|c|}{ BUSINESS ACTIVITIES } \\
\hline Planning & 52 & 21 & 40.4 & 51 & 19 & 37.3 & 53 & 21 & 39.6 \\
\hline Design & 49 & 18 & 36.7 & 48 & 17 & 35.4 & 47 & 17 & 36.2 \\
\hline Production/conversion & 61 & 29 & 47.5 & 61 & 29 & 47.5 & 61 & 29 & 47.5 \\
\hline Employee training & 43 & 15 & 34.9 & 44 & 15 & 34.1 & 44 & 15 & 34.1 \\
\hline Research and development & 56 & 24 & 42.9 & 54 & 22 & 40.7 & 54 & 22 & 40.7 \\
\hline Total business activities & 309 & 125 & 40.5 & 305 & 119 & 39.0 & 47 & 17 & 36.2 \\
\hline \multicolumn{10}{|c|}{ OUTPUTS } \\
\hline Products & 63 & 31 & 49.2 & 62 & 30 & 48.4 & 62 & 30 & 48.4 \\
\hline Services & 62 & 31 & 50.0 & 60 & 29 & 48.3 & 60 & 29 & 48.3 \\
\hline By-products & 28 & 11 & 39.3 & 28 & 13 & 46.4 & 28 & 13 & 46.4 \\
\hline Waste & 36 & 11 & 30.6 & 36 & 12 & 33.3 & 36 & 12 & 33.3 \\
\hline Total outputs & 189 & 84 & 44.4 & 186 & 84 & 45.2 & 186 & 84 & 45.2 \\
\hline \multicolumn{10}{|c|}{ OUTCOMES } \\
\hline Customer satisfaction & 49 & 19 & 38.8 & 49 & 18 & 36.7 & 49 & 18 & 36.7 \\
\hline Profit/loss & 64 & 32 & 50.0 & 61 & 30 & 49.2 & 61 & 30 & 49.2 \\
\hline Shareholder return & 57 & 28 & 49.1 & 51 & 24 & 47.1 & 51 & 24 & 47.1 \\
\hline Asset consumption & 43 & 19 & 44.2 & 41 & 18 & 43.9 & 41 & 18 & 43.9 \\
\hline
\end{tabular}


Table 3. Cont.

\begin{tabular}{|c|c|c|c|c|c|c|c|c|c|}
\hline \multirow{3}{*}{ Disclosure } & \multicolumn{3}{|c|}{2019} & \multicolumn{3}{|c|}{2018} & \multicolumn{3}{|c|}{2017} \\
\hline & \multirow{2}{*}{ Total } & \multicolumn{2}{|c|}{ Only Financial Information } & \multirow{2}{*}{ Total } & \multicolumn{2}{|c|}{ Only Financial Information } & \multirow{2}{*}{ Total } & \multicolumn{2}{|c|}{ Only Financial Information } \\
\hline & & In Number & $\%$ Total & & In Number & $\%$ Total & & In Number & $\%$ Total \\
\hline Job creation & 47 & 17 & 36.2 & 46 & 17 & 37.0 & 46 & 17 & 37.0 \\
\hline Employee development and engagement & 43 & 15 & 34.9 & 41 & 14 & 34.1 & 41 & 14 & 34.1 \\
\hline Improved standard of living & 52 & 22 & 42.3 & 51 & 21 & 41.2 & 51 & 21 & 41.2 \\
\hline Environment impact & 45 & 18 & 40.0 & 42 & 15 & 35.7 & 42 & 15 & 35.7 \\
\hline Licence to operate & 48 & 16 & 33.3 & 46 & 15 & 32.6 & 46 & 15 & 32.6 \\
\hline Contribution to local economy through taxes & 57 & 26 & 45.6 & 54 & 24 & 44.4 & 54 & 24 & 44.4 \\
\hline Total outcomes & 505 & 212 & 42.0 & 482 & 196 & 40.7 & 482 & 196 & 40.7 \\
\hline Total & 1298 & 535 & 41.2 & 1262 & 512 & 40.6 & 1001 & 410 & 41.0 \\
\hline
\end{tabular}


Empirical data confirm the dominant descriptive disclosures about the BM. There is also a lot of financial (numerical) information disclosed in the enterprises surveyed but not more than non-financial disclosures. The percentage of financial information in total information constitutes over $40 \%$ in all specified components (total). The largest proportion of financial disclosures in total information was recorded for the outputs category $(44.4 \%$; $45.2 \% ; 45.2 \%$ in periods examined), while the lowest proportion of financial disclosures was recorded for the business activities category (36.2\% in 2017).

The next stage of the research was devoted to the examination of the correlation between the sum of disclosures about the BM in selected components and economic parameters achieved by these enterprises in 2019, 2018 and 2017. The results of the correlation dependence are presented in Table 4 . All statistically significant correlations are marked with colour (greater than 0.3493 with a significance level of 0.05 ). Table 4 presents the Spearman rank correlations for the total disclosures of the surveyed enterprises in the specified components with selected economic parameters. It should be noted that there are quite numerous statistically significant correlations, but that these correlations are not strong. No statistically significant correlations were noted for the total of all disclosures about liabilities and total assets. There were also no statistically significant correlations for only financial disclosures for the parameter: total assets. The highest statistically significant correlation for the total of components that were disclosed was found for the parameter EBITda in 2017 (0.5543), while the least significant correlation was identified for the same parameter in 2019 (0.3516). Within the detailed data, the highest statistically significant correlations were found only in 2017 between EBITda and outcomes at the level of total disclosures (0.6613), and between EBITda and outputs at the level of only financial disclosures (0.6152). What is clearly visible in the presented data is the fact that the strength of the correlation decreases over the years. This result is very interesting but also puzzling, and in-depth research is required into its causes in further research. 
Table 4. Spearman's rank correlation coefficient for total disclosures and only financial disclosures. ${ }^{1}$

\begin{tabular}{|c|c|c|c|c|c|c|c|c|c|c|c|c|c|c|c|c|c|c|}
\hline \multirow{2}{*}{ Disclosures } & \multicolumn{3}{|c|}{ Total Assets [Million] } & \multicolumn{3}{|c|}{ Performance } & \multicolumn{3}{|c|}{ Board-No of Members } & \multicolumn{3}{|c|}{ EBITda } & \multicolumn{3}{|c|}{ Equity } & \multicolumn{3}{|c|}{ Liabilities } \\
\hline & 2019 & 2018 & 2017 & 2019 & 2018 & 2017 & 2019 & 2018 & 2017 & 2019 & 2018 & 2017 & 2019 & 2018 & 2017 & 2019 & 2018 & 2017 \\
\hline \multicolumn{19}{|c|}{ Total disclosures } \\
\hline Inputs & -0.2065 & -0.1515 & -0.1428 & -0.0699 & 0.2279 & 0.3794 & -0.1512 & -0.0724 & -0.0507 & 0.2402 & 0.3376 & 0.4385 & 0.3038 & 0.3679 & 0.3616 & -0.2836 & -0.2367 & -0.2263 \\
\hline Business activities & -0.2024 & -0.1397 & -0.1507 & -0.0613 & 0.2470 & 0.3937 & -0.2528 & -0.0891 & 0.0067 & 0,2756 & 0.3797 & 0.4610 & 0.3215 & 0.3710 & 0.3715 & -0.2822 & -0.2243 & -0.2371 \\
\hline Outputs & -0.1590 & -0.1119 & -0.0828 & -0.0763 & 0.2681 & 0.4315 & -0.1172 & 0.0190 & 0.1292 & 0.3420 & 0.4377 & 0.5293 & 0.3874 & 0.4292 & 0.4353 & -0.2462 & -0.2045 & -0.1743 \\
\hline Outcomes & 0.1885 & 0.2744 & 0.2438 & 0.1093 & 0.4317 & 0.5299 & 0.2288 & 0.3882 & 0.3501 & 0.4844 & 0.6091 & 0.6613 & 0.4993 & 0.5949 & 0.5695 & 0.1180 & 0.1912 & 0.1607 \\
\hline Total & -0.1557 & -0.0528 & -0.0676 & -0.0478 & 0.3698 & 0.5030 & -0.1602 & 0.0281 & 0.1050 & 0.3516 & 0.5058 & 0.5543 & 0.4204 & 0.4965 & 0.4713 & -0.2485 & -0.1519 & -0.1639 \\
\hline \multicolumn{19}{|c|}{ Only financial disclosures } \\
\hline Inputs & -0.3352 & -0.3357 & -0.3407 & -0.1454 & 0.1344 & 0.2780 & -0.3128 & -0.3124 & -0.3011 & 0.1433 & 0.1977 & 0.2961 & 0.2165 & 0.2394 & 0.2367 & -0.4101 & -0.4161 & -0.4212 \\
\hline Business activities & -0.3271 & -0.2148 & -0.2262 & -0.1175 & 0.2171 & 0.3612 & -0.4001 & -0.2043 & -0.1030 & 0.1836 & 0.3273 & 0.4062 & 0.2383 & 0.3204 & 0.3207 & -0.4052 & -0.2977 & -0.3109 \\
\hline Outcomes & -0.1923 & -0.0752 & -0.0690 & -0.0568 & 0.3666 & 0.4994 & -0.1720 & 0.0267 & 0.1152 & 0.3066 & 0.4853 & 0.5303 & 0.3732 & 0.4706 & 0.4555 & -0.2804 & -0.1718 & -0.1623 \\
\hline Total & -0.2665 & -0.1617 & -0.1575 & -0.1016 & 0.3126 & 0.4542 & -0.2900 & -0.0969 & 0.0041 & 0.2701 & 0.4269 & 0.4883 & 0.3453 & 0.4255 & 0.4124 & -0.3575 & -0.2589 & -0.2520 \\
\hline
\end{tabular}


The correlation of the specified components of the BM with the same parameters was examined also; however, the authors focused only on the financial disclosures. Here as well, the correlations are quite numerous but not very strong (see Table 4 ). The highest significant correlation for the sum of disclosures was identified for the EBITda category in 2017 (0.4883), while the lowest significant correlation concerns the relationship between the sum of financial disclosures and the liabilities category in 2019 (-0.3575). It should be noted that the strongest and most numerous correlations identified, both in terms of financial and total disclosures, were with the parameters-financial result (performance), EBITda and equity.

This confirms that entities with a stronger market position and better financial results use reporting tools based on the BM to a greater extent, which confirms the assumption that more effective enterprises use more advanced techniques and tools, including those for communication with stakeholders. The research did not fully confirm a dominant relationship in the literature indicating that the size of an enterprise is a factor that determines the number of disclosures. Such a statistically significant relationship was demonstrated in studies by Manes-Rossi et al. [84] into the relationship between university size and information on intellectual capital.

There was no significant correlation between the number of disclosures about the BM and total assets. However, significant correlations occurred with equity, as well as with the results achieved by enterprises (performance, EBITda). It can therefore be said that the results of the research are similar to those obtained by Czaja-Cieszyńska, Lulek and Sadowska [92], pp. 134-135, which confirmed that the scope of non-financial disclosures among Polish companies is at different levels, and that a company's affiliation to the WIG-ESG index does not guarantee a comprehensive approach to non-financial reporting.

\section{Practical Implications of Informing about the Business Model}

In order to meet stakeholders' expectations on publication of information about the $\mathrm{BM}$, entities are undertaking more and more activities, e.g., for sustainable development, or related to environmental protection, employee training and protection of employees' health. These activities are then broadly reflected in non-financial reports, for which there is an increasing demand. As a result, by popularizing the problem of reporting the BM, also via this study, enterprises can compete better with one another on the market through the use of information provided in reports, especially regarding sustainable development.

Such reporting is positively perceived by stakeholders. Thus, research on reporting about the BM indirectly contributes to positive behaviour among entrepreneurs and supports the concept of sustainable development.

The authors also believe that in-depth analyses of informing about the BM may have further practical implications - they contribute to an increase in the transparency of this notion. For example, the presented research compares enterprises that publish an integrated report and those that do not publish such a report, amongst others those providing information about the BM in an orderly manner and those that publish information in a disorderly manner. The desired effect is therefore that more and more enterprises publish non-financial reports, including information about the BM, in an orderly manner according to established guidelines, for example GRI.

On the other hand, providing information about the BM is of managerial importance for enterprises. Positive behaviours are then introduced into the management of the company for supporting and conducting sustainable development. In particular, opportunities are identified, and the non-financial dimension that contributes to the value creation process is understood more deeply, which significantly supports the company's management processes. Integrated thinking requires an in-depth awareness and comprehension of the company's BM, which is necessary in the introduction of sustainable processes and business management in the spirit of sustainable development. However, managers need to find a trade-off between confidentiality and transparency of information about the firm's activities, without neglecting investors and the information needs of other stakeholders. 
Competition between enterprises in the area of data reporting may cause the amount of reported information to increase. From a practical point of view, our results can support a better understanding of the disclosure of the business model by standards setters. They can better understand to what extent current standards support the disclosure of the BM, including information on sustainable development [5] and in what direction their development should be carried out. The research results allow us to indicate that the BM is not only a tool that describes the way an enterprise creates value, but also carries managerial potential in that it can shape specific attitudes and behaviours, which are then reported in order to legitimize the actions taken by the enterprise. This area has not yet been heavily exploited, but it is likely to be further developed and explored by researchers, especially against the background of legitimacy theory and stakeholder theory.

\section{Discussion}

The study confirms that entities that prepare an integrated report are characterized by a greater number of disclosures of the BM components in selected economic categories compared with entities that do not prepare an integrated report. Therefore, it can be stated that the results for hypothesis 1 confirm the relationship between the number of BM component disclosures and whether or not enterprises prepare an integrated report.

This allows us to recognize that the integrated report is an important tool from the perspective of recognizing the information needs of various stakeholder groups, which concurs with the mainstream of stakeholder theory. This is consistent with the results obtained by Manes-Rossi et al. [93]. The researchers examined the importance of the IR as a transparency and accountability tool in the context of state-owned enterprises, using a sample of European SOEs in the period 2013-2017, in accordance with IR framework requirements. This study assumes, as it also focuses on stakeholder theory and legitimacy theory, that the IR is an accountability tool which combines a wide range of information that meets the information needs of both shareholders and stakeholders [93].

In the view of the authors, from a stakeholder theory perspective, it can also be assumed that increasing scrutiny by society in general [63], promoted by the IIRC guidelines, results in enhanced stakeholder expectations. In line with these guidelines, the BM is one of the main topics in the future development of organization reporting and a key element of integrated reporting. In turn, organisations facing a higher number of stakeholders and their expectations will improve their disclosure about the BM.

The system of legal regulations and accounting standards is a determinant which has a significant impact on the reporting system of enterprises. We are convinced that an important factor that limits sufficient development of the studied area is that International Accounting Standards and the Polish Accounting Act address the issue of the BM insufficiently [40]. The Polish Accounting Act requires large entities only to present a statement of non-financial information, which includes a brief description of an entity's BM [94]. We also base our conclusions on the results of research by Ahmed Haji and Anifowose [95], which focuses on analysis of disclosure practices before and after the introduction of integrated reporting in large South African companies. Based on the theoretical framework of institutional legitimation, they showed an increase in the level of disclosure of information in the field of human and intellectual capital after the IR practice was adopted.

Moreover, the reluctance of enterprises to present a wide range of reporting which is required by legal regulations was disclosed. The scope of disclosures in the analysed research sample was strongly determined by the applicable standards and regulations. Fonseca [49] and Jenkins and Yakovleva [96] reached similar conclusions in their research.

The examined companies are large entities, which is why it can be concluded that they disclose more information and adopt international guidelines. The results are similar to those of Jensen and Berg [67] and Reverte [3], who analysed the relationship between firm size and CSR disclosure. It can also be assumed that organizations follow what other similar organizations do, which indicates the mimetic isomorphism indicated by DiMaggio and Powell [97] in their research. The occurrence of similar practices is also evident in 
our study. When we compare the results regarding disclosures by enterprises in the nonfinancial and financial sector (Table 2), we see a lower number of disclosures about the MB in enterprises representing the financial sector (banks). Our results are similar to those presented by Cooray et al. [98], which show that there is an increase in disclosures and that the non-financial sector has better reporting performance then the financial sector. In their article, Cooray et al. [99] also show that non-financial sector companies in Sri Lanka have a better quality of IR.

Another topic discussed is the predominance of the descriptive narrative form. The results of the research confirmed the hypothesis 2 and revealed the predominance of the narrative descriptive form about the BM in relation to the amount of disclosed financial (numerical) information. This is consistent with the results of Lai et al. [31] and Walinska et al. [53], which demonstrated the predominance of the narrative nature of reporting and that the financial information was significantly limited. The value that stakeholders derive from an integrated report is influenced by its readability [100]. This effect is particularly strong in the case of integrated reporting implemented in narrative form, which facilitates dialogue with various stakeholders [3]. From the point of view of stakeholder theory, greater readability of an integrated report in which information about the BM is presented in narrative form can be considered as a tool used by management to signal activities which are in their best interest. In this context, the BM turns out to be essential also for the implementation of managerial activities.

However, it should be clearly emphasized that the predominance of a narrative disclosures is not significant in our study. There were quite a few financial disclosures about the BM, although slightly less than descriptive disclosures. Therefore, the authors conclude that the $\mathrm{BM}$ is a reporting area that has great information potential also for presenting financial information. This, in turn, is a step towards increasing the transparency and comparability of these reporting issues which, according to stakeholder theory, will balance and mitigate conflicts of interest between shareholders and other stakeholders [101].

Research results indicate that the $\mathrm{BM}$ is disclosed in a rather detailed manner by enterprises, and confirms the results obtained by Lai et al. [31]. However, BM information is reported in a highly fragmented manner and, as a result, it "loses" its information potential. This finding coincides with that of Page [38]. Even entities that prepare an integrated report do not necessarily include all elements reported of the BM in such a report. This information is dispersed and disclosed in multiple reports. These results are consistent with those of other researchers [55]. This proves that the BM in reporting is not clearly distinguishable for a large proportion of Polish enterprises, which is of great importance in pursuing the goal of sustainable development of corporate reporting.

Thus, there is no clear combination of BM components. The features of transparency, usability and comparability can therefore not be retained.

The presented research forms a backdrop to the ongoing broad discussion about the relationship between and impact of selected economic parameters of an enterprise on reporting practice, as well as the relationship between disclosures and the usefulness of information for stakeholders. It may also contribute to an increase in the amount of some economic parameters, such as share prices or financial results, as well as non-financial parameters which are the basis of sustainable development in the long term. This is partially consistent with research conducted by A. and M. Jabłoński [15], according to which the BM of companies at an early stage of their development (for those listed on the Warsaw Stock Exchange) is oriented primarily toward how the company shapes, delivers and captures value from the market in order to generate profits for shareholders and increase the value of the company. Meanwhile, the business models of mature companies include the intentions of management, used to balance objectives with respect to different groups of stakeholders and to carefully formulate and implement business objectives with particular attention paid to preserving the sustainability of the business. 
The present research confirms the existence of a relationship between the level of detail in reporting on the BM and selected economic parameters of an enterprise (mainly performance, EBITda, equity and board), which led us to confirm the Hypothesis 3.

Correlation dependencies indicate that the dominant part of the studied variables affect disclosure strategies for enterprises' business models. There is a growing awareness of disclosures, about outcomes, and their information potential in shaping the decisions of various groups of users of business reports.

All examined cases (outside the sum of assets) demonstrated a significant correlation. Such a relationship exists because more accurate disclosures increase the usefulness of reporting information, which works as an incentive for potential investors or customers. The relationship between disclosures and economic parameters has also been confirmed by other studies [65-67].

Additionally, the indicated relationships provide the basis for the discussion on the concept of information efficiency of capital markets, which is part of the theory of capital market efficiency and is adopted in many financial models. The research by Czekaj et.al [102] shows that only the hypothesis of poor information efficiency can be accepted in the case of Poland. The research conducted by the authors also confirms a weak relationship between the amount of information about the BM and selected economic parameters.

However, somewhat surprisingly, the research results did not confirm the results of other researchers showing that the amount of reporting on the BM is increasing [54,56]. This may be the result of a certain stagnation of reporting during the initial period after the new disclosure requirements were introduced and may also be due to the short period covered by the study. It should be emphasized that the results were preceded by a preliminary study by the authors on a smaller group of entities for only two years (2017-2018). Nevertheless, the results showed a similar pattern.

\section{Conclusions}

This study examined the BM disclosures of selected listed companies and banks. The high level of detail in reporting elements about the BM was confirmed. In addition, it was significantly higher in the companies preparing an integrated report. Moreover, the mentioned reporting group presented information about the BM in a more comprehensive manner. Therefore, based on the assumptions of the institutional theory, it can be concluded that the accounting principles and standards have a significant impact on increasing the quality of disclosures and the scope of BM reporting. A similar relationship concerns the size and financial efficiency of the enterprise. In the remaining enterprises, the reporting result in the examined area was more chaotic and dispersed.

The authors recommend supplementing and structuring previously reported nonfinancial and financial information with information on sustainable development, and also recommend including this aspect in the company's BM. The authors believe that this is a natural consequence of the development of BM description.

As well as suggested by Gerwanski et al. [101], we also recommend the issuance of a "best practice guide" for materiality disclosure, specifically for first-year reporters. Accompanied by practical examples, this could supplement the existing background paper on materiality [10]. Clear guidance might increase reporting homogeneity, persuade hesitant managers to adopt IR, increase the diffusion of IR and the BM concept, and leverage the acceptance of the new reporting medium among investors and other stakeholders.

The authors also consider that the research results have a strong implication for standard setters in determining the direction of the future form of standards. The existence of additional regulations is an important factor that ensures the sustainable development of reporting on the BM to satisfy the additional information needs of various stakeholders.

The research contributes as well to accounting literature because it provides evidence that the field of accounting is developing and is adopting practical solutions, especially in the field of reporting. Bearing in mind that the main aim of reporting is to provide information for decision-making, our study sheds light on important elements of financial 
and non-financial reporting and on new elements that shape the new scope of reports. This research is in line with other studies on the development of accounting.

Notwithstanding, the present study has some limitations. Firstly, the small research sample should be mentioned. This is justified by the short period the surveyed companies had to prepare integrated reports, as well as the time and space-limited requirements for reporting on the BM. As indicated above, there are still few companies listed on the Warsaw Stock Exchange that prepare an integrated report. This limitation is also the basis for determining the directions of future research, which will, inter alia, refer to a longer time horizon. Another limitation is focusing on one country, which can, however, be seen as the basis for conducting further in-depth research over a wider territorial scope and, at the same time, is a useful comparative basis for other researchers.

The synthesis of the obtained research results allows the BM to be considered as an important, future-oriented tool in the area of enterprise reporting, but also as a tool that has significant management potential. However, it is rather descriptive in form, which is justified due to the subject matter that often relates to specific activities and broad external dimensions (including social and environmental ones) that are difficult to present in financial terms. At the same time, for reporting purposes, it is recommended that regulations be developed to limit the spread and lack of comparability of data, as well as the existing chaos and oversaturation of information. Undoubtedly, however, BM is a tool for strengthening ties between the enterprise and stakeholders.

The authors consider it necessary to develop research on the BM, including the epistemological layer, which could increase the comparability of integrated reports between enterprises. This is consistent with the current discussion trend in the literature [40,41,103,104], although there are also well-known voices that question research into the BM in accounting [6]. We believe that developing research on BM reporting is a crucial step toward in development of a sustainable BM using the digital environment, as well as development of a social BM [105]. A particularly interesting direction for future research concerns the use of the BM as a tool for legitimizing enterprises' actions in relation to the theory of legitimation. An area that is also significant is further development of the relationship between accounting and the BM using the assumptions of institutional theory. It will be necessary to observe the changes in reporting on the BM under the influence of the introduction of legal and similar regulations, as well as the diffusion of knowledge about this concept and its impact on the usefulness of the reported data.

Finally, this paper contributes also to broader research on the topic of BM disclosure in reporting and to improve its usefulness for its users. The discussion on the BM contributes to the growing interest of enterprises in this reporting spectrum, which is a positive phenomenon for the increase in market information efficiency.

Author Contributions: A.S., B.D.-K. and A.F. conceived of the presented idea; A.S., B.D.-K. and A.F. developed the methodology and framework; A.S., B.D.-K., A.F. performed the study, drafted the manuscript; A.F., B.D.-K. and A.S. designed the figure; A.S., B.D.-K. and A.F. encouraged and supervised the study and analysis. All authors discussed and contributed to the final manuscript. All authors have read and agreed to the published version of the manuscript.

Funding: This research was funded within a subsidy for the maintenance and development of research potential of the University of Economics in Katowice, Poland.

Data Availability Statement: The data that support the findings of this study are available from the beatakania@ue.katowice.pl upon reasonable request.

Acknowledgments: The authors are grateful to Jan Acedański (University of Economics in Katowice) and Piotr Kania (University of Economics in Katowice) for statistical consultations, as well as three anonymous reviewers whose remarks and comments significantly contributed to the development of the presented article.

Conflicts of Interest: The authors declare no conflict of interest. 


\section{References}

1. Tweedie, D.; Nielsen, C.; Martinov-Bennie, N. The business model in integrated reporting: Evaluating concept and application. Aust. Account. Rev. 2018, 28, 405-420. [CrossRef]

2. Teece, D.J.; Pisano, G.; Shuen, A. Dynamic capabilities and strategic management. Strateg. Manag. J. 1997, 18, 509-533. [CrossRef]

3. Reverte, C. Determinants of corporate social responsibility disclosure ratings by Spanish listed firms. J. Bus. Ethics 2009, 88, 351-366. [CrossRef]

4. Ogden, S.; Clarke, J. Customer disclosures, impression management and the construction of legitimacy. Account. Audit. Account. J. 2005, 18, 313-345. [CrossRef]

5. Guthrie, J.; Manes-Rossi, F.; Orelli, R.L.; Nicolò, G. Investigating risk disclosures in Italian integrated reports. Meditari Account. Res. 2020, 28, 1149-1178. [CrossRef]

6. Sorrentino, M.; Smarra, M. The Term “Business Model” in Financial Reporting: Does It Need a Proper Definition? Open J. Account. 2015, 4, 11-22. [CrossRef]

7. Zott, C.; Amit, R.; Massa, L. The business model: Recent developments and future research. J. Manag. 2011, 37, 1019-1042. [CrossRef]

8. Amit, R.; Zott, C. Value creation in e-business. Strateg. Manag. J. 2001, 22, 493-520. [CrossRef]

9. ICAEW. Business Models in Accounting: The Theory of the Firm and Financial Reporting; Institute of Chartered Accountants in England and Wales: London, UK, 2010.

10. IIRC. The International Framework. Integrated Reporting. 2013. Available online: https://integratedreporting.org/wp-content/ uploads/2015/03/13-12-08-THE-INTERNATIONAL-IR-FRAMEWORK-2- (accessed on 11 October 2020).

11. Osterwalder, A.; Pigneur, Y.; Tucci, C.L. Clarifying Business Models: Origins, Present, and Future of the Concept. Communications of the Association for Information Systems. 2005. Available online: http://aisel.aisnet.org/cais/vol16/iss1/1v (accessed on 1 January 2021).

12. Teece, D.J. Business models, business strategy and innovation. Long Range Plan. 2010, 43, 172-194. [CrossRef]

13. Beattie, V.; Smith, S.J. Value creation and business models: Refocusing the intellectual capital debate. Br. Account. Rev. 2013, 45, 243-254. [CrossRef]

14. Schaltegger, S.; Hansen, E.; Lüdeke-Freund, F. Business models for sustainability: Origins, present research, and future avenues. Organ. Environ. 2016, 29, 3-10. [CrossRef]

15. Jabłoński, A.; Jabłoński, M. Research on business models in their life cycle. Sustainability 2016, 8, 430. [CrossRef]

16. CIMA; IFAC; PwC. Business Model: Background Paper for IR. 2013. Available online: https://www.ifac.org/about-ifac/ professional-accountants-business/publications-resources/business-model-background-paper (accessed on 17 September 2020).

17. Disle, C.; Périer, S.; Bertrand, F.; Gonthier-Besacier, N.; Protin, P. Business Model et normalisation comptable: Quelle intégration du modèle économique par les IFRS? Comptab. Controle Audit 2016, 22, 85-119. [CrossRef]

18. Clark, T.; Osterwalder, A.; Pigneur, Y. Model Biznesowy Ty; Helion: Gliwice, Poland, 2013.

19. Karwowski, M. Model Biznesu w Sprawozdaniu Finansowym. Ograniczenia Informacyjne; Oficyna Wydawnicza SGH, Szkoła Główna Handlowa w Warszawie: Warsaw, Poland, 2018.

20. Krasodomska, J. Informacje Niefinansowe w Sprawozdawczości Spótek, Zeszyty Naukowe; Seria Specjalna Monografia; Uniwersytet Ekonomiczny w Krakowie: Krakaw, Poland, 2014.

21. Evan, W.; Freeman, E. A Stakeholder Theory of the Modern Corporation; Kantian Capitalism. In An Introduction to Business Ethics; Chryssides, G.D., Kaler, J.H., Eds.; Chapman and Hall: London, UK, 1993.

22. Śnieżek, E.; Piłacik, J. Raportowanie informacji pozafinansowych o społecznej odpowiedzialności w Lasach Państwowych w świetle niektórych koncepcji teoretycznych. Studia Ekon. 2016, 284, 140-149.

23. Scott, W.R. Approaching adulthood: The maturing of institutional theory. Theor. Soc. 2008, 37, 427-442. [CrossRef]

24. Christensen, D.M. Corporate accountability reporting and high-Profile misconduct. Account. Rev. 2016, 9, 377-381. [CrossRef]

25. Dratwińska-Kania, B.; Kania, P. Corporate Social Responsibility in Poland and Abroad-A Comparative Analysis. Ecology, Economics, Education and Legislation. In Proceedings of the 13th SGEM GeoConference on Ecology, Economics, Education and Legislation, Albena, Bulgaria, 16-22 June 2013; Volume II, pp. 655-662. Available online: www.sgem.org (accessed on 6 September 2021).

26. Nielsen, A.E.; Thomsen, C. Reporting CSR-what and how to say it? Corp. Commun. Int. J. 2007, 12, 25-40. [CrossRef]

27. Hahn, R.; Kühnen, M. Determinants of sustainability reporting: A review of results, trends, theory, and opportunities in an expanding field of research. J. Clean. Prod. 2013, 59, 5-21. [CrossRef]

28. Kolk, A. Sustainability, accountability and corporate governance: Exploring multinationals' reporting practices. Bus. Strategy Environ. 2008, 17, 1-15. [CrossRef]

29. Świderska, G.K.; Bek-Gaik, B. Dokąd zmierza raportowanie biznesowe? Studia Ekon. 2016, 274, 7-15.

30. Zsóka, Á.; Vajkai, É. Corporate sustainability reporting: Scrutinising the requirements of comparability, transparency and reflection of sustainability performance. Soc. Econ. 2018, 40, 19-44. [CrossRef]

31. Lai, A.; Melloni, G.; Stacchezzini, R. Disclosing Business Model in the "Integrated Report": Evidence from European Early Adopters. In Proceedings of the AIDEA Bicentenary Conference, Leece, UK, 19-21 September 2013. Available online: http: //www.aidea2013.it/docs/400_aidea2013_accounting.pdf (accessed on 1 February 2021). 
32. Akisik, O.; Gal, G. Sustainability in businesses, corporate social responsibility, and accounting standards: An empirical study. Int. J. Account. Inf. Manag. 2011, 19, 304-324. [CrossRef]

33. Eccles, R.G.; Krzus, M.P. One Report: Integrated Reporting for a Sustainable Strategy; John Wiley \& Sons: Hoboken, NJ, USA, 2010.

34. Eccles, R.G.; Serafeim, G.; Krzus, M. Market interest in nonfinancial information. J. Appl. Corp. Financ. 2011, $23,113-127$. [CrossRef]

35. Kannenberg, L.; Schreck, P. Integrated reporting: Boon or bane? A review of empirical research on its determinants and implications. J. Bus. Econ. 2019, 89, 515-567. [CrossRef]

36. Serafeim, G. Integrated Reporting and Investor Clientele; Working Paper; Harvard University: Cambridge, MA, USA, 2014.

37. Beck, C.; Dumay, J.; Frost, G. In Pursuit of a "Single Source of Truth": From Threatened Legitimacy to Integrated Reporting. J. Bus. Ethics 2017, 141. [CrossRef]

38. Page, M. Business models as a basis for regulation of financial reporting. J. Manag. Gov. 2012, 18, 683-695. [CrossRef]

39. Simnett, R.; Huggins, A.L. Integrated reporting and assurance: Where can research add value? Sustain. Account. Manag. Policy J. 2015, 6, 29-53. [CrossRef]

40. Bek-Gaik, B.; Rymkiewicz, B. Model Biznesu w Raportowaniu Organizacji-Wybrane Problemy. Pr. Nauk. Uniw. Ekon. Wrocławiu 2017, 471, 23-33.

41. Lambert, S. A Conceptual Framework for Business Model Research. BLED 2008 Proceedings, p. 24. 2008. Available online: https: / / aisel.aisnet.org/bled2008/24 (accessed on 6 September 2021).

42. Malola, A.; Maroun, W. The measurement and potential drivers of integrated report quality. Evidence from a pioneer in integrated reporting. S. Afr. J. Account. Res. 2019, 33, 114-144. [CrossRef]

43. Szewieczek, A.; Sulik-Górecka, A. Behavioral determinants of the business model in the financial statement-On the example of selected industries. Res. Pap. Wroc. Univ. Econ. 2018, 515, 197-208. [CrossRef]

44. Graaff, B.; Steens, B.; Camfferaman, K. Integrated Reporting: Much Ado about Nothing. 2019. Available online: https: / / papers.ssrn.com/sol3/papers.cfm?abstract_id=3382322 (accessed on 29 November 2020).

45. Woźniak, J.; Pactwa, K. Analysis of the socio-environmental policy of selected mining companies on the basis of non-financial reporting. Miner. Resour. Manag. 2019, 35, 177-194.

46. Perez, F.; Sanchez, L.E. Assessing the Evolution of Sustainability Reporting in the Minisnf Sector. Environ. Manag. 2009, 43, 949-961. [CrossRef]

47. Bini, L.; Giunta, F.; Bellucci, M. Integrating sustainability in business model disclosure: Evidence from the UK mining industry. $J$. Clean. Prod. 2017, 171, 1161-1170. [CrossRef]

48. Ferens, A. Cyberbezpieczeństwo i cyberryzyko w raportach zintegrowanych i sprawozdaniach zarządu operatorów usług kluczowych. Zesz. Teor. Rachun. 2021, in press.

49. Fonseca, A. How credible are mining corporations' sustainability reports? A critical analysis of external assurance under the requirements of the international council on mining and metals. Corp. Soc. Responsib. Environ. Manag. 2010, 17, 355-370. [CrossRef]

50. Bini, L.; Dainell, I.F.; Giunta, F. Business model disclosure in the Strategic Report. J. Intellect. Cap. 2016, 17, 83-102. [CrossRef]

51. Melloni, G.; Caglio, A.; Perego, P. Saying more with less? Disclosure conciseness, completeness and balance in Integrated Reports. J. Account. Public Policy 2017, 36, 220-238. [CrossRef]

52. Clarkson, P.M.; Li, Y.; Richardson, G.D.; Vasvari, F.P. Revisiting the relation between environmental performance and environmental disclosure: An empirical analysis. Account. Organ. Soc. 2008, 33, 303-327. [CrossRef]

53. Walińska, E.; Bek-Gaik, B.; Gad, J. Informacje finansowe i niefinansowe w raporcie zintegrowanym-praktyka spółek notowanych na Giełdzie Papierów Wartościowych w Warszawie. Zesz. Teor. Rachun. 2018, 100, 167-189.

54. Bek-Gaik, B.; Rapacz, A. Model biznesu w raportach zintegrowanych polskich spółek giełdowych. Finans. Rynk. Finans. Ubezpieczenia 2018, 2, 209-222.

55. Bek-Gaik, B.; Rymkiewicz, B. Model biznesu w sprawozdawczości organizacji-Ocena ujawnień w sprawozdaniu z działalności, Finanse. Rynk. Finans. Ubezpieczenia 2017, 85, 201-214.

56. Bek-Gaik, B.; Rymkiewicz, B. Model biznesu w raportowaniu zintegrowanym. Pr. Nauk. Uniw. Ekon. Wroctawiu 2016, $442,32-51$.

57. Bek-Gaik, B.; Rymkiewicz, B. Model biznesu w sprawozdawczości polskich spółek publicznych na przykładzie branży energetycznej. Res. Pap. Wroc. Univ. Econ. 2015, 398, 36-52.

58. Maniora, J. Is Integrated Reporting Really the Superior Mechanism for the Integration of Ethics into the Core Business Model? Empir. Anal. J. Bus. Ethics 2017, 140, 755-786. [CrossRef]

59. Garcia-Sánchez, I.M.; Rodríguez-Ariza, L.; Frías-Aceituno, J.V. The cultural system and integrated reporting. Int. Bus. Rev. 2013, 22, 828-838. [CrossRef]

60. Frías-Aceituno, J.V.; Rodríguez-Ariza, L.; García-Sánchez, I.M. Is integrated reporting determined by a country's legal system? An exploratory study. J. Clean. Prod. 2013, 44, 45-55. [CrossRef]

61. Kılıç, M.; Kuzey, C. Assessing current company reports according to the IIRC integrated reporting framework. Meditari Account. Res. 2018, 26, 305-333. [CrossRef]

62. Stent, W.; Dowler, T. Early assessments of the gap between integrated reporting and current corporate reporting. Meditari Account. Res. 2015, 23, 92-117. [CrossRef] 
63. Nicolò, G.; Zanellato, G.; Tiron-Tudor, A. Integrated Reporting and European State-Owned Enterprises: A disclosure analysis pre and post 2014/95/EU. Sustainability 2020, 12, 1908. [CrossRef]

64. Havemo, E. A visual perspective on value creation: Exploring patterns in business model diagrams. Eur. Manag. J. 2018, 36, 441-452. [CrossRef]

65. Kang, T.; Pang, Y.H. Economic Development and the Value-Relevance of Accounting Information-A Disclosure Transparency Perspective. Rev. Account. Financ. 2015, 4, 5-31. [CrossRef]

66. Verrecchia, R.E. Essays on disclosure. J. Account. Econ. 2001, 32, 97-180. [CrossRef]

67. Jensen, J.C.; Berg, N. Determinants of traditional sustainability reporting versus integrated reporting. An institutionalist approach. Bus. Strategy Environ. 2012, 21, 299-316. [CrossRef]

68. Rivera-Arrubla, Y.A.; Zorio-Grima, A.; García-Benau, M.A. Integrated reports: Disclosure level and explanatory factors. Soc. Responsib. J. 2017, 13, 155-176. [CrossRef]

69. Dratwińska-Kania, B. Transparentność Rachunku Wyniku z Operacji Funduszu Inwestycyjnego-Ujęcie Teoretyczne i Propozycja Pomiaru, Pr. Naukowe; Uniwersytet Ekonomiczny w Katowicach: Katowice, Poland, 2018.

70. Gamerschlag, R.; Möller, K.; Verbeeten, F. Determinants of voluntary CSR disclosure: Empirical evidence from Germany. Rev. Manag. Sci. 2011, 2-3, 233-262. [CrossRef]

71. Roberts, R.W. Determinants of corporate social responsibility disclosure: An application of stakeholder theory. Account. Organ. Soc. 1992, 17, 595-612. [CrossRef]

72. Cowen, S.S.; Ferreri, L.B.; Parker, L.D. The impact of corporate characteristics on social responsibility disclosure: A typology and frequency-based analysis. Account. Organ. Soc. 1987, 12, 111-122. [CrossRef]

73. Patten, D.M. Exposure, legitimacy, and social disclosure. J. Account. Public Policy 1991, 10, 297-308. [CrossRef]

74. Dratwińska-Kania, B.; Ferens, A.; Szewieczek, A. Raportowanie Zintegrowane o Modelu Biznesu w Kreowaniu Wartości Przedsiębiorstwa; CeDeWu: Warsaw, Poland, 2021.

75. Mechelli, A.; Cimini, R.; Mazzocchetti, F. The usefulness of the business model disclosure for investors' judgements in financial entities. A European study: Utilidad de la divulgación del modelo de negocio para los criterios de inversores en entidades financieras. Un estudio europeo. Rev. Contab. Span. Account. Rev. 2017, 20, 1-12. [CrossRef]

76. Van Zijl, W.; Wostmann, C.; Maroun, W. Strategy disclosures by listed financial services companies: Signalling theory, legitimacy theory and South African integrated reporting practices. S. Afr. J. Bus. Manag. 2017, 48, 73-85. [CrossRef]

77. Ungerer, M. A comparative analysis of strategy disclosure reporting trends in South Africa in 2010. S. Afr. Bus. Rev. 2013, 17, 27-56.

78. Sukhari, A.; De Villiers, C. The Influence of Integrated Reporting on Business Model and Strategy Disclosures. Aust. Account. Rev. 2018, 29, 708-725. [CrossRef]

79. Mohammad, N. Integrated Reporting Practice and Disclosure in Bangladesh's_Banking Sectors. Indones. J. Sustain. Account. Manag. 2019, 3, 147-161. [CrossRef]

80. Deegan, C.; Rankin, M. Do Australian companies report environmental news objectively? Account. Audit. Account. J. 1996, 9, 50-67. [CrossRef]

81. Guthrie, J.; Parker, L.D. Corporate social disclosure practice: A comparative international analysis. Adv. Public Interest Account. 1990, 3, 159-175.

82. Donnelly, R.; Mulcahy, M. Board structure, ownership, and voluntary disclosure in Ireland. Corp. Gov. Int. Rev. 2008, 16, 416-429. [CrossRef]

83. Samaha, K.; Khlif, H.; Hussainey, K. The impact of board and audit committee characteristics on voluntary disclosure: A meta-analysis. J. Int. Account. Audit. Tax. 2015, 24, 13-28. [CrossRef]

84. Manes-Rossi, F.; Christiaens, J.; Aversano, N. Accountability through intellectual capital disclosure in Italian Universities. J. Manag. Gov. 2020, 24, 1055-1087.

85. Vitolla, F.; Raimo, N.; Rubino, M. Board characteristics and integrated reporting quality: An agency theory perspective. Corp. Soc. Responsib. Environ. Manag. 2020, 27, 1152-1163. [CrossRef]

86. Gandía, J.L. Determinants of internet-based corporate governance disclosure by Spanish listed companies. Online Inf. Rev. 2008, 32, 791-817. [CrossRef]

87. Uwuigbe, U.N.; Egbide, B.C.; Ayokunle, A.M. The effect of board size and board composition on firms' corporate environmental disclosure: A study of selected firms in Nigeria. Acta Univ. Danub. Econ. 2011, 7, 176.

88. Said, R.; Zainuddin, Y.H.; Haron, H. The relationship between corporate social responsibility disclosure and corporate governance characteristics in Malaysian public listed companies. Soc. Responsib. J. 2009, 5, 212-226. [CrossRef]

89. Juhmani, O.I. Ownership structure and corporate voluntary disclosure: Evidence from Bahrain. Int. J. Account. Financ. Rep. 2013, 3, 133. [CrossRef]

90. Jenson, M.C.; Meckling, W.H. Theory of the firm: Managerial behavior, agency costs and ownership structure. J. Financ. Econ. 1976, 3, 305-360. [CrossRef]

91. Aczel, A.D. Statystyka w Zarzadzaniu (Complete Business Statistics); Polish Scientific Publishers PWN: Warsaw, Poland, 2000.

92. Czaja-Cieszyńska, H.; Lulek, A.; Sadowska, B. Informacyjna Funkcja Rachunkowości z Perspektywy Społecznej Odpowiedzialności Biznesu; University of Szczecin: Szczecin, Poland, 2021. 
93. Manes-Rossi, F.; Nicolò, G.; Tudor, A.T.; Zanellato, G. Drivers of integrated reporting by state-owned enterprises in Europe: A longitudinal analysis. Meditari Account. Res. 2020, 29, 586-616. [CrossRef]

94. Accounting Act of 29th September 1994. Journal of Laws. 2019. Available online: https:// sip.lex.pl/akty-prawne/dzu-dziennikustaw / rachunkowosc-16796295 (accessed on 1 August 2021).

95. Haji, A.A.; Anifowose, M. Initial trends in corporate disclosures following the introduction of integrated reporting practice in South Africa. J. Intellect. Cap. 2017, 18, 373-399. [CrossRef]

96. Jenkins, H.; Yakovleva, N. Corporate social responsibility in the mining industry: Exploring trends in social and environmental disclosure. J. Clean. Prod. 2006, 14, 271-284. [CrossRef]

97. DiMaggio, P.J.; Powell, W.W. The Iron Cage Revisited: Institutional Isomorphism and Collective Rationality in Organizational Fields. Am. Sociol. Rev. 1983, 48, 147-160. [CrossRef]

98. Cooray, T.; Senaratne, S.; Gunarathne, N.; Herath, R.; Samudrage, D.N. Adoption of integrated reporting in Sri Lanka: Coverage and trend. J. Financ. Rep. Account. 2021. ahead of print. [CrossRef]

99. Cooray, T.; Gunarathne, A.D.N.; Senaratne, S. Does corporate governance affect the quality of integrated reporting? Evidence from Sri Lanka. Sustainability 2020, 12, 4262. [CrossRef]

100. du Toit, E. The readability of integrated reports. Meditari Account. Res. 2017, 25, 629-653. [CrossRef]

101. Gerwanski, J.; Kordsachia, O.; Velte, P. Determinants of materiality disclosure quality in integrated reporting: Empirical evidence from an international setting. Bus. Strategy Environ. 2019, 28, 750-770. [CrossRef]

102. Czekaj, J.; Woś, M.; Żarnowski, J. Efektywność Giełdowego Rynku Akcji w Polsce. Z Perspektywy Dziesięciolecia; Polish Scientific Publishers PWN: Warsaw, Poland, 2001.

103. Kozarkiewicz, A. Model biznesu a system rachunkowości zarządczej w przedsiębiorstwie. Pr. Nauk. Uniw. Ekon. Wrocławiu 2013, 289, 323-331.

104. Michalak, J. Modele Biznesu Przedsiębiorstw. Analiza i Raportowanie; Wydawnictwo Uniwersytetu Łódzkiego: Łódź, Poland, 2016.

105. Jabłoński, A.; Jabłoński, M. Social Business Models in the Digital Economy. New Concepts and Contemporary Challenges; Palgrave Macmillan: London, UK, 2020. 